\title{
Comparative study of 24-hour urinary protein and spot urine protein creatinine ratio in pre-eclamptic women
}

\author{
Rupakala B. M., Akshata S. Hiremath*
}

Department of Obstetrics and Gynecology, Rajarajeswari Medical College and Hospital, Bangalore, Karnataka, India

Received: 24 April 2021

Accepted: 28 May 2021

\section{*Correspondence:}

Dr. Akshata S. Hiremath,

E-mail: akshatahiremath1@gmail.com

Copyright: () the author(s), publisher and licensee Medip Academy. This is an open-access article distributed under the terms of the Creative Commons Attribution Non-Commercial License, which permits unrestricted non-commercial use, distribution, and reproduction in any medium, provided the original work is properly cited.

\begin{abstract}
Background: The aim of the study was to evaluate the ability of the random urine $\mathrm{P} / \mathrm{C}$ ratio to predict significant proteinuria, as well as to introduce a diagnostic test for pre-eclampsia which will avoid the inconvenience and time consumption of 24-hour urine protein collection. The objective of this study was to compare spot urine proteincreatinine ratio with 24-hour urine protein for estimation of proteinuria in pre-eclampsia.

Methods: A total of 50 pregnant women with pre-eclampsia were prospectively studied for proteinuria in Rajarajeswari medical college and Hospital Bangalore for a period of 9 months from September 2018 to May 2019. Spot urine specimens for measuring $\mathrm{P} / \mathrm{C}$ ratio were obtained immediately before 24-hour urine collection. The correlation between the spot urine $\mathrm{P} / \mathrm{C}$ ratio and urinary protein excretion in the 24-hour collections was examined using the Spearman correlation test.

Results: PCR at a cut off value $0.15 \mathrm{~g} / \mathrm{mmol}$ had sensitivity and specificity of $96.6 \%$ and $55 \%$ respectively. In prediction of proteinuria of $300 \mathrm{mg} / 24 \mathrm{hr}$ positive predictive value and negative predictive value $76.3 \%$ and $91.6 \%$ respectively.

Conclusions: We found that there was a strong correlation between 24-hour urine protein excretion and spot urine protein creatinine ratio in pre-eclamptic women. Spot PCR can be used as a reasonable alternative to 24-hour urine protein test which is a cumbersome.
\end{abstract}

Keywords: 24-Hour urine protein, Spot urine protein creatinine ratio, Pre-eclampsia

\section{INTRODUCTION}

Pre-eclampsia is the third leading cause of maternal mortality worldwide and is a leading cause of perinatal mortality and morbidity. The WHO estimates around 600,000 women will die each year from pre-eclampsia. ${ }^{1}$ Pre-eclampsia complicates $2-8 \%$ of all pregnancies; it is a multisystem endothelial disease that leads to increased permeability of glomerular basement membrane to protein with resulting proteinuria. ${ }^{2}$ Pre-eclampsia is diagnosed with elevated blood pressure (systolic $\geq 140$ and diastolic $\geq 90$ ) and proteinuria ( $>300 \mathrm{mg} / 24 \mathrm{hr}$ ) after the 20 weeks of gestation in a previously normotensive non-proteinuric patient. ${ }^{3}$ Proteinuria is one of the most important sign of preeclampsia, and diagnosis is questionable in its absence. Protein excretion in a 24-hour urine collection and its measurement has been the long-standing gold-standard but time-consuming test for the quantitative evaluation of proteinuria induced by preeclampsia. A more rapid test capable of accurately predicting the results of a 24-hour urine would be valuable. Measurement of protein creatinine ratio in spot urine sample is an alternate quantitative method for evaluation of proteinuria, which avoids the influence of variations in concentration of urinary solute and provides a rapid and more convenient method to assess protein excretion.

Clinical use of urine $\mathrm{P} / \mathrm{C}$ ratio as a substitute of 24-hour urine protein excretion for detecting significant proteinuria in patients with preeclampsia still remains unclear. Some investigators have proposed the use of a spot urine PCR. ${ }^{4,5}$ However, there are some reports with conflicting results, and the variability in cut-off values between studies does not allow a uniform recommendation. ${ }^{6,7} \mathrm{We}$ correlated 
between spot urine $\mathrm{P} / \mathrm{C}$ ratio and 24-hour urine protein excretion in patients being evaluated for preeclampsia.

The aim of the study was to evaluate the ability of spot urine protein creatinine ratio to predict significant proteinuria, as well as to introduce this test as a diagnostic test for pre-eclampsia to avoid the inconvenience and time consumption of 24-hour urine protein collection.

\section{METHODS}

Pregnant women who were admitted in our obstetrics department with pre-eclampsia were studied prospectively. The study was conducted at Rajarajeswari medical college and hospital Bangalore, tertiary care centre, between September 2018 and May 2019, and the local ethics committee approved the study design.

Pre-eclampsia was defined as a blood pressure of 140/90 $\mathrm{mmHg}$ or higher after the 20th week of gestation and a urine protein of $1+$ or greater by dipstick test or chronic hypertension without proteinuria before the 20th week followed by new-onset urine protein of $1+$ or greater by dipstick test. Women with the following conditions known kidney disease, heavy exercise (more than 1 hour of vigorous exercise on the day of urine collection), bacteriuria, bed rest longer than 24 hours, and gestational diabetes mellitus were exluded. A total of 50 pregnant women meeting the inpatient admission criteria for the evaluation of preeclampsia were prospectively recruited and provided informed written consent.

Urine was collected for 24-hour. Prior to the collection, the patients also provided a spot mid-stream sample. The urine $\mathrm{P} / \mathrm{C}$ ratio on spot urine specimens was determined. The total protein concentration in urine was measured by a biuret colorimetric assay and the urine creatinine level was measured by a modified Jaffe test.

The urine PCR was obtained by dividing the urinary protein concentration by the urine creatinine concentration. Measurements on the 24-hour urine sample were performed on the same day as collections were completed.

\section{Statistical analysis}

The correlation between PCR in spot urine samples and urinary protein excretion in 24-hour collections were analysed. Sensitivity, specificity, and predictive values of the random urine PCR at various cut-offs for prediction of significant proteinuria were estimated considering the 24hour urinary protein excretion as the gold standard.

The receiver operating characteristic (ROC) curve was used, and the area under the curve (AUC) was calculated. The relationship between the urine PCR and the 24-hour protein excretion was assessed with the Pearson correlation test. A $p$ value $\leq 0.05$ was considered significant.

\section{RESULTS}

A total of 50 women with pre-eclampsia admitted in our obstetric department were recruited for the study prospectively. Their mean age was $26 \pm 2$ years $(\mathrm{SD}=3.8)$, 27 were primigravid women, the mean gestational age was $32.1 \pm 2.8$ weeks (range from $28^{+2}$ to $38^{+2}$ weeks). The mean SBP and DBP was 149.04 $\pm 9.1 \mathrm{mmHg}$ and 95.28 \pm 5.3 $\mathrm{mmHg}$ respectively. The mean urinary protein excretion in 24 -hour urine collections was $0.77 \pm 0.89 \mathrm{~g} / \mathrm{dl}$. The mean $\mathrm{P} / \mathrm{C}$ ratio was $1 \pm 1.18$. $\mathrm{P} / \mathrm{C}$ ratio against the 24 -hour urine protein excretion was found to be 0.84 . The positive predictive value and negative predictive values for $\mathrm{P} / \mathrm{C}$ ratio were $76.3 \%$ and $91.6 \%$ respectively. The sensitivity and specificity were found to be $96.6 \%$ and $55 \%$ respectively.

Table 1: Demographic details of the patients by presence or absence of significant proteinuria in 24-hour urine collection.

\begin{tabular}{|c|c|c|}
\hline $\begin{array}{l}\text { Dermographic } \\
\text { variables }\end{array}$ & $\begin{array}{l}<300 \mathrm{mg} / \mathrm{dl} \\
(\mathrm{N}=20)\end{array}$ & $\begin{array}{l}>300 \mathrm{mg} / \mathrm{dl} \\
(\mathrm{N}=30)\end{array}$ \\
\hline Age (mean \pm SD) & $27.25,3.93$ & $25.63,3.74$ \\
\hline \multirow{3}{*}{ Parity } & 11 & 16 \\
\hline & 4 & 10 \\
\hline & 5 & 4 \\
\hline $\begin{array}{l}\text { Admission gestational } \\
\text { age }\end{array}$ & $32+5$ & $33+2$ \\
\hline $\begin{array}{l}\text { SBP in } \mathbf{m m H g} \\
(\mathrm{mean} \pm \mathrm{SD})\end{array}$ & $144.1,5.67$ & $152.3,9.64$ \\
\hline $\begin{array}{l}\text { DBP in mmHg } \\
(\text { mean } \pm \text { SD })\end{array}$ & $92.9,3.14$ & $96.8,6.00$ \\
\hline
\end{tabular}

Table 2: Sensitivity, specificity, negative and positive predictive value for the spot test against the 24-hour urine protein collection.

\begin{tabular}{|c|c|}
\hline Variables & $\begin{array}{l}\text { PCR cut-off value } \\
0.15(\mathrm{~g} / \mathrm{mmol})\end{array}$ \\
\hline Sensitivity (\%) & 96.6 \\
\hline Specificity (\%) & 55 \\
\hline Positive predictive value (\%) & 76.3 \\
\hline Negative predictive value (\%) & 91.6 \\
\hline Positive likelihood ratio & 2.15 \\
\hline Negative likelihood ratio & 0.06 \\
\hline AUC & 0.935 \\
\hline
\end{tabular}

Table 3: Correlation between blood pressure, PCR and 24-hour urine protein.

\begin{tabular}{|lllll|} 
Correlation & $\begin{array}{l}\text { 24-hour } \\
\text { urine } \\
\text { protein }\end{array}$ & SBP & DBP \\
\hline PCR & $\begin{array}{l}\text { Pearson } \\
\text { correlation (r) }\end{array}$ & 0.769 & 0.711 & 0.546 \\
\hline P value & $<0.01^{*}$ & $<0.01^{*}$ & $<0.01^{*}$ \\
\hline
\end{tabular}

*Significant $\leq 0.05$ 


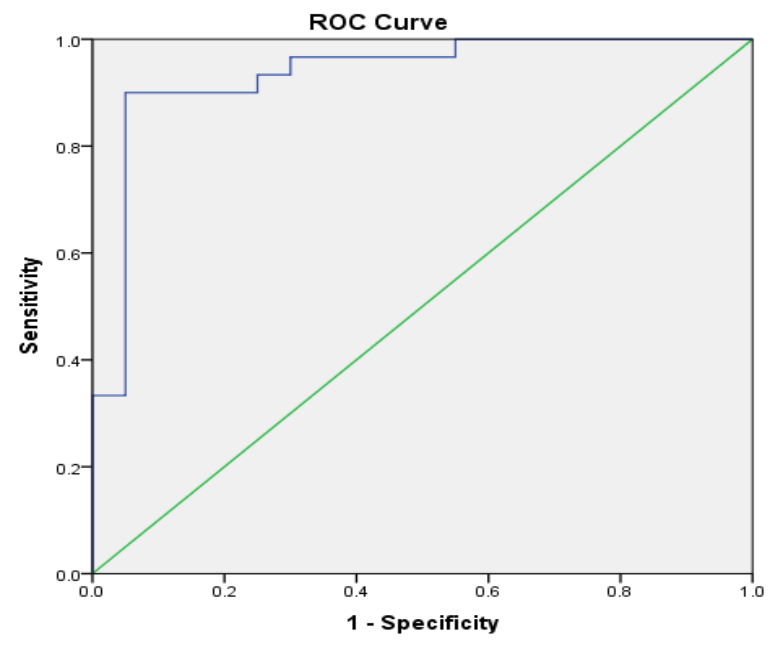

Figure 1: Receiver operating characteristic curves (ROCs) for the urine protein-creatinine ratio.

In Figure 1, the area under the ROC curve for the urine protein-creatinine ratio is 0.93 (95\% CI 0.86 to 1$)$.

The areas under the curve is significantly different $(\mathrm{p}<0.001)$.

\section{DISCUSSION}

The finding of significant proteinuria is an essential component in the diagnosis of pre-eclampsia, which helps in determining the risk of maternal and perinatal morbidity and mortality. Early diagnosis and treatment of preeclampsia is essential for prevention of eclampsia. On the other hand, accurate diagnosis is important to prevent unnecessary interventions in hypertensive pregnant women.

Although 24-hour urine collection for total protein estimation is still used as the gold standard test. It has many disadvantages: it is inconvenient for both patients and staff, cost, delay in diagnosis and management. In addition, errors are possible such as incomplete collection which may result in missed diagnoses. ${ }^{8}$ PCR can be a practical alternative test which would minimise such errors and facilitate prompt and early clinical decision making. ${ }^{6}$ This test can rapidly be repeated in an evolving clinical situation. This would also impact healthcare costs such a staff time and in-patient costs and reduce patient anxiety while awaiting the results. ${ }^{5}$ One of the other methods most commonly used is the urinary dipstick test because of its simplicity and low cost. But this method has high false positive and false negative result rates associated with fluctuations throughout the day due to water intake, exercise, diet, posture, or improperly trained laboratory staff. ${ }^{9-11}$ Thus, a more rapid and accurate diagnostic test that is capable of predicting 24-hour urine protein excretion would be valuable.

In this study, we propose the use of random urine $\mathrm{P} / \mathrm{C}$ ratio to facilitate prompt decision making by clinicians. ${ }^{12,13} \mathrm{We}$ determined the correlation between spot urine PCR and 24-hour urine protein excretion prospectively. Urine was collected from patients who satisfied admission criteria for pre-eclampsia, and the spot urine value obtained at the beginning of the 24-hour collection period was compared with the result acquired from the 24-hour urine collection, to see if these values were correlated. A good correlation between the spot urine $\mathrm{P} / \mathrm{C}$ ratio and 24-hour protein excretion has been demonstrated in patients with diabetic nephropathy, lupus nephritis, chronic kidney disease, and transplanted kidneys. ${ }^{14-17}$ The National Kidney Foundation guidelines have suggested that spot urine samples should be used to detect and monitor proteinuria in children and adults. $^{18}$

In our study, a urine $\mathrm{P} / \mathrm{C}$ ratio of 0.15 corresponded with a protein excretion rate of $300 \mathrm{mg} / 24 \mathrm{hr}$. These are characterized by excellent accuracy. Consistent with most previous studies with correlation coefficients ranging between 0.80 and 0.97 , we found a strong correlation $(\mathrm{r}=0.84)$ between the spot $\mathrm{P} / \mathrm{C}$ ratio and the 24-hour urine protein. ${ }^{9,19-, 21}$ However, using the spot $\mathrm{P} / \mathrm{C}$ ratio of 0.20 as a correlate to the critical value of $300 \mathrm{mg}$ of protein over 24 hours would result in the failure to identify significant proteinuria in approximately $8.8 \%$ of affected patients.

There are some reports with conflicting results. Because of the variability for measuring proteinuria in different reported studies, several cut-off points and different units for the urinary $\mathrm{P} / \mathrm{C}$ ratio have been reported, thereby precluding valid comparisons among such studies. ${ }^{20-22}$ Systematic reviews have evaluated literature and have come to similar conclusions. $^{25}$

In an analysis by Cote et al, the spot $\mathrm{P} / \mathrm{C}$ ratio had a pooled sensitivity of $83.6 \%$ and specificity of $76.3 \%$ using a cut off of 0.26 to predict proteinuria $>300 \mathrm{mg}$ /day in a 24 -hour collection, concluding that $\mathrm{P} / \mathrm{C}$ is a reasonable rule out test for excluding proteinuria. ${ }^{26} \mathrm{~A}$ more recent meta-analysis by Morris et al including 2790 women had similar 
findings: a single diagnostic threshold of 0.3 had a sensitivity and specificity of $81 \%$ and $76 \%$ respectively. A lower cut off $(0.13)$ had better $(89 \%)$ sensitivity for exclusion of proteinuria. ${ }^{27}$ Taken together, these data suggest that a urine $\mathrm{P} / \mathrm{C}$ ratio $>0.7$ strongly predicts significant proteinuria whereas a $\mathrm{P} / \mathrm{C}$ ratio $<0.15$ can be considered normal, so confirmation with 24 hour urine collection probably is not necessary in these individuals. ${ }^{28}$ If a 24-hour urine collection is not obtained, guidelines define proteinuria as random $\mathrm{P} / \mathrm{C}$ ratio $>0.26$.

Our study suggested that the random urine $\mathrm{P} / \mathrm{C}$ ratio is a highly accurate test for discriminating between insignificant and significant proteinuria, as demonstrated by an area under the ROC curve of 0.93 . To obtain the optimal cut-off, we selected the one that while increasing specificity maintains a sensitivity of higher than $90 \%$ in order to reduce the possibility of missing the diagnosis of pre-eclampsia. Research in the future should be focused on the evaluation of clinical outcomes and the cost effectiveness of the use of a random spot urinary PCR for prediction of significant proteinuria. In addition, studying the test in an outpatient basis should be further considered in order to apply it in ambulatory management of preeclamptic patient. We suggest that further evaluations be done in order to determine a cut-off value for prediction of mild pre-eclampsia.

\section{CONCLUSION}

Based on the results of our study, we conclude that random urine $\mathrm{P} / \mathrm{C}$ ratios can predict 24 -hour urine protein excretion with a high accuracy. This test can also be used as an alternative to 24-hour urine protein excretion, it could also complement the urinary dipstick test in preeclamptic pregnancy. Further study needs to be conducted for evaluation of clinical outcomes and the cost effectiveness of use of random urinary PCR for prediction of significant proteinuria.

\section{Funding: No funding sources}

Conflict of interest: None declared

Ethical approval: The study was approved by the Institutional Ethics Committee

\section{REFERENCES}

1. WHO. WHO recommendations for prevention and treatment of pre-eclampsia and eclampsia: implications and actions. Geneva: WHO; 2014.

2. Duley L, Meher S, Abalos E. Management of preeclampsia. BMJ. 2006;332(7539):463-8.

3. Cote AM, Firoz T, Mattman A, Lam EM, von Dadelszen P, Magee LA. The 24-hour urine collection: gold standard or historical practice? Am J Obstet Gynecol. 2008;199(6):625.

4. Al RA, Baykal C, Karacay O, Geyik PO, Altun S, Dolen I. Random urine protein-creatinine ratio to predict proteinuria in new-onset mild hypertension in late pregnancy. Obstet Gynecol. 2004;104(2):367-71.
5. Boulware LE, Jaar BG, Tarver CME, Brancati FL, Powe NR. Screening for proteinuria in US adults: a cost- effectiveness analysis. JAMA. 2003;290(23):3101-14.

6. Durnwald C, Mercer B. A prospective comparison of total protein/creatinine ratio versus 24-hour urine protein in women with suspected preeclampsia. Am J Obstet Gynecol. 2003;189(3):848-52.

7. Haas DM, Sabi F, Namara M, Rivera AM. Comparing ambulatory spot urine protein/creatinine ratios and 24$\mathrm{h}$ urine protein measurements in normal pregnancies. J Matern Fetal Neonatal Med. 2003;14(4):233-6.

8. Lindheimer MD, Kanter D. Interpreting abnormal proteinuria in pregnancy: the need for a more pathophysiological approach. Obstet Gynecol. 2010;115(2):365-75.

9. Saudan PJ, Brown MA, Farrell T, Shaw L. Improved methods of assessing proteinuria in hypertensive pregnancy. $\mathrm{Br} \quad \mathrm{J}$ Obstet Gynaecol. 1997;104(10):1159-64.

10. Bell SC, Halligan AW, Martin A, Ashmore J, Shennan AH, Lambert PC, et al. The role of observer error in antenatal dipstick proteinuria analysis. $\mathrm{Br} \mathrm{J}$ Obstet Gynaecol. 1999;106:1177-80.

11. Rizk DE, Agarwal MM, Pathan JY, Obineche EN. Predicting proteinuria in hypertensive pregnancies with urinary protein-creatinine or calciumcreatinine ratio. J Perinatol. 2007;27:272-7.

12. Roudsari FV, Ayati S, Ayatollahi H, Shakeri MT. Protein/creatinine ratio on random urine samples for prediction of proteinuria in preeclampsia. Hypertens Pregnancy. 2012;31(2):240-2.

13. Sethuram R, Kiran TS, Weerakkody AN. Is the urine spot protein/creatinine ratio a valid diagnostic test for pre-eclampsia? J Obstet Gynaecol. 2011;31(2):12830 .

14. Christopher SL, Petri M, Astor BC, Fine D. Urine protein-to-creatinine ratio is a reliable measure of proteinuria in lupus nephritis. $\mathbf{J}$ Rheumatol. 2004;31(8):1557-9.

15. Chitalia VC, Kothari J, Wells EJ, Livesey JH, Robson RA, Searle M, et al. Cost-benefit analysis and prediction of 24-hour proteinuria from the spot urine protein-creatinine ratio. Clin Nephrol. 2001;55:43647.

16. Xin G, Wang M, Jiao LL, Xu GB, Wang HY. Proteinto-creatinine ratio in spot urine samples as a predictor of quantitation of proteinuria. Clin Chim Acta. 2004;350(1):35-9.

17. Torng S, Rigatto C, Rush DN, Nickerson P, Jeffery JR. The urine protein to creatinine ratio $(\mathrm{P} / \mathrm{C})$ as a predictor of 24-hour urine protein excretion in renal transplant patients. Transplantation. 2001;72:1453-6.

18. Keane WF, Eknoyan G. Proteinuria, albuminuria, risk, assessment, detection, elimination (PARADE): a position paper of the National Kidney Foundation. Am J Kidney Dis. 1999;33(5):1004-10.

19. Robert M, Sepandj F, Liston RM, Dooley KC. Random protein-creatinine ratio for the quantitation 
of proteinuria in pregnancy. Obstet Gynecol. 1997;90(6):893-5.

20. Neithardt AB, Dooley SL, Borensztajn J. Prediction of 24-hour protein excretion in pregnancy with a single voided urine protein-to-creatinine ratio. Am J Obstet Gynecol. 2002;186(5):883-6.

21. Rodriguez TD, Lieberman ES. Use of a random urinary protein-to-creatinine ratio for the diagnosis of significant proteinuria during pregnancy. Am J Obstet Gynecol. 2001;185(4):808-11.

22. Yamasmit W, Chaithongwongwatthana S, Charoenvidhya D, Uerpairojkit B, Tolosa J. Random urinary protein-to-creatinine ratio for prediction of significant proteinuria in women with preeclampsia. $\mathbf{J}$ Matern Fetal Neonatal Med. 2004;16(5):275-9.

23. Zadehmodarres S, Razzaghi MR, Habibi G, Najmi Z, Jam H, Mosaffa N, Kaboosi M. Random urine protein to creatinine ratio as a diagnostic method of significant proteinuria in pre-eclampsia. Aust N Z J Obstet Gynaecol. 2006;46(6):501-4.

24. Wheeler TL, Blackhurst DW, Dellinger EH, Ramsey PS. Usage of spot urine protein to creatinine ratios in the evaluation of preeclampsia. Am J Obstet Gynecol. 2007;196(5):465.
25. Stout MJ, Scifres CM, Stamilio DM. Diagnostic utility of urine protein-to-creatinine ratio for identifying proteinuria in pregnancy. J Matern Fetal Neonatal Med. 2013;26(1):66-70.

26. Cote AM, Brown MA, Lam E, Dadelszen P, Firoz T, Liston RM, et al. Diagnostic accuracy of urinary spot protein:creatinine ratio for proteinuria in hypertensive pregnant women: systematic review. BMJ. 2008;336(7651):1003-6.

27. Morris RK, Riley RD, Doug M, Deeks JJ, Kilby MD. Diagnostic accuracy of spot urinary protein and albumin to creatinine ratios for detection of significant proteinuria or adverse pregnancy outcome in patients with suspected pre-eclampsia: systematic review and meta-analysis. BMJ. 2012;345.

28. Visintin C, Mugglestone MA, Almerie MQ, Nherera LM, James D, Walkinshaw S, et al. Management of hypertensive disorders during pregnancy: summary of NICE guidance. BMJ. 2010;341:2207.

Cite this article as: Rupakala BM, Hiremath AS. Comparative study of 24-hour urinary protein and spot urine protein creatinine ratio in pre-eclamptic women. Int J Reprod Contracept Obstet Gynecol 2021;10:2734-8. 